OF THE

BRITISH SOCIETY

FOR THE

\title{
HISTORY OF SCIENCE
}

\section{Presidential Address}

\section{Reflections on the Writing of the History of Science}

\author{
Delivered by Dr. F. SheRwood Taylor on 13th May, 1953.
}

I have chosen as the subject of my Presidential Address the Writing of the History of Science, of which I have done enough at least to discover the difficulties, and perhaps to entitle me to say that the apparatus of teaching and research available to the historian of science is notably inferior to that possessed by the general historian or by the scientist. In the term History of Science, I do not intend to include the History of Technology, although the two cannot in practice be wholly separated. It will be known to most of you that a very considerable work on the History of Technology is now in preparation in this country, and it is to be hoped that this will remedy many of the defects and deficiencies that have hindered the study of this subject. I shall, indeed, express the hope that such a work may be undertaken in the field of the history of pure science, but before I make such a suggestion I would wish to consider some of the underlying conditions for the provision of an apparatus of research in this subject.

The apparatus of teaching and research in our subject consists of museums and writings, of which the latter are necessarily more important because they can be in the student's hand, because they survey aspects of the science of the past that are not expressed in any objects, and because they reach back to distant times from which scarcely any relic of science has survived. The writings from which we learn the history of science are, first, the works of scientists of bygone days, secondly, the writings of modern historians of science. Nothing can be done about the former except to edit them and make them available, a work which is slowly proceeding, but which at present is unlikely to extend beyond the works of which a publisher can hope to sell a few hundred copies. The research worker can, nay must, go to the originals, but the student, in this as in every subject, must depend largely upon modern surveys, whether published in periodicals or in separate books. This is the subject to which I wish to advert today.

What is the present state of writings on the History of Science? There are, I would say at once, a few good journals, and in my opinion sufficient to publish the not very heavy crop of good papers that are prepared by the few serious workers in the field. Among periodicals on the history of science in general we appreciate the great work done by Isis, Osiris, Annals of Science, Archeion and Lychnos. On specialised aspects of the subject, I would mention the Journal of the Newcomen Society on the history of Engineering ; Ambix on Alchemy and Early Chemistry ; Janus, Archiv für Geschichte der Medizin, 
Annals of Medical History and one or two others in that field; Eudemus on the history of Mathematics and Astronomy. Add to these fifty or so periodicals that publish a proportion of articles on the subject, and it would seem that we are not ill-served. In fact, I have not heard that their editors are forced to reject first-class papers through lack of space, but rather that they find it hard to obtain contributions of the requisite standard.

I should not feel I had done justice to the great Institution which I serve if $I$ did not also mention the 95 handbooks issued by the Science Museum, many of which contain full and accurate histories of their subject in addition to descriptive catalogues of objects. These are, I think, volumes which, considering their low price, are too rarely at the hand of the scientific writer.

When we turn to books concerned with the History of Science we find a profusion of them, of which the great majority are specialised accounts of some small field. The only general works on the history of Science are those of the late Sir W. C. Dampier, F. Dannemann's more extensive but little known work Die Naturwissenschaften in ihrer Entwicklung und in ihrem Zusammenhange, Sedgwick \& Tylor's Short History of Science, Dr. Singer's Short History of Science to the Nineteenth Century and my own not very extensive contribution. The monumental works of Sarton and Thorndike deal only with the period before Science was science in the modern sense, Wolf's with the period from the Renaissance to the end of the nineteenth century, and Pledge's from the former up to today. I do no wrong to the works of Sir W. C. Dampier, Sedgwick \& Tylor, Dr. Singer and myself, when I say that they do not take the reader beyond a very elementary stage and are adapted rather for those who wish to begin an acquaintance with the subject than for those who wish to make a deep study or to find the means of reference to topics more recondite than those that are familiar to the ordinary educated person.

The individual sciences are better catered for. In Mathematics Cantor holds the field, but is, I am told, in much need of revision. Of the histories of Physics, none in my opinion, is adequate to the great importance of the subject. In the field of Chemistry, we have the admirable short history of Professor J. R. Partington, but no work at once solid and extensive since that of Kopp, now a century old-since which time Chemistry has grown a new history. The histories of Biology are also too brief for the scholar : medicine on the other hand has been much better treated. The great Systéme du Monde of $\mathrm{P}$. Duhem may be regarded as one of the finest works we have, passing from astronomy and physics to the general history of early science. In addition to these general histories of subjects, there are great numbers of studies of periods, smaller departments of science and individual scientists, works very properly limited in time or in scope.

In writing about such a mass of books, it is hard to generalise and every generalisation is likely to be falsified by some shining instance to the contrary: yet, I will pluck up my courage, and put forth the thesis that "the history of science is written by amateurs for amateurs". All of us have found, in any subject we have troubled to investigate, that text-books contain serious errors, which have often made it transparently clear that the writer had not consulted the original sources, indeed had sometimes not consulted any source except his own imagination. I sometimes wonder why people believe that they can write the history of science by inspiration, when in any other field they would take care to verify their facts. There is in fact a bad tradition of irresponsibility in the writing of the history of science, which has made some of us unwilling to read text-books because we do not credit the authors with reasonable 
scholarship. We treat them as guilty till we prove them innocent: there are a few of whom we can say "we can rely on him " - and some of them in this Society-but we have to discover for ourselves who they are.

I hope, then, that I carry you with me when I say that we need better apparatus of study for our subjects, and especially general histories of science and its departments, adapted to the serious student. Now may I turn to the difficulties of providing such books, difficulties which reside in the men that write them, their intentions in writing them and the people that publish and read them?

What sort of being ought to write the history of science ? If he is attempting to write a first-class comprehensive general book he requires a remarkable equipment. In the first place he has to know Seience. Is there any of us who can claim to do this even in modest measure, who could write an elementary article on any and every major department of science and make no elementary blunder? Yet one cannot fully write the history of science without understanding the sciences in such a way as to recognise past anticipations of or failures to anticipate the modern view.

Nor is it only science that is needed. Most of the mediaeval scientists and those of the Renaissance and seventeenth century were philosophers, and we can only appreciate their contribution to science if we understand the philosophical attitude that they adopt or initiate. It is no light task to understand scholastic philosophy. We have one or two historians of science that do so, but we must also note how much at least one such philosopher, Gilson, has contributed to the understanding of mediaeval science.

Thirdly, the historian of science should know something of religion. It is obvious that the mediaeval natural philosopher contemplated a world explained equally in terms of theology, philosophy and science, and that his interests in the various departments of science and his favourable or unfavourable views of certain theories were much influenced by religious dogmata: nor is this true only of the middle ages, for in every previous age theology and natural philosophy mutually influenced each other.

Fourthly, the writer on the history of science ought to be a historian as well as a scientist. We have seen in the works of Professor Butterfield how the historian can throw new light on the history of science, yet it is generally true to say that historian and scientist are at cross-purposes, asking the wrong questions of each other and giving them infertile answers.

Fifthly, we have to find a man who knows the tongues. For the older generation

"Latin was no more difficile

Than to a blackbird 'tis to whistle",

and our nineteenth century historians

$$
\text { As naturally as pigs squeak ". }
$$

But today the students of the history of science struggle with Latin and baulk at Greek. Even nearer to us, such a great man as Paracelsus is almost unread in England because of the antique German in which his works are couched. All scholars, you may say, have these troubles : but we suffer from them most, because of the limited scope of the education of scientists, and also because our stock of translations is but small.

Lastly he must be equipped with a pen. How well and clearly the men of the eighteenth and early nineteenth centuries wrote their histories: how 
few of us can wield the pen with grace-yet here I cannot but mention Professor Andrade, whose incursions into this field we should like to see multiplied.

So much then for the personal equipment of the man. Diogenes would carry his lantern a long while before he found him. And why ? Because there is but slender hope of a professional career for a historian of science. In this country we have one professorship partly directed to this subject and half a dozen lectureships and readerships, all comparatively newly founded. We need academic positions for which a man should begin to prepare himself at seventeen so that, after forty years of continuous full-time work, he should be fitted to write from a fullness of knowledge and trained judgment.

Even such a man would be human and subject to our common errors. He would belong to a nation. Read a German history of science and an English: you will be surprised at the different percentages of names of either origin in the index. Thus in the index of a certain German history of science 11 per cent. of the names are English : in that of a randomly selected English work of the same scope, 31 per cent. This is not due to such conscious propaganda as may be found elsewhere, but rather to a better acquaintance with those who were at the writer's university, taught his teachers, wrote in his language. Perhaps this problem will never be solved, but as the history of science becomes more professional it will be mitigated. Our historian must, moreover, have a world-view, if he is to be a good historian. If he has none, he will write a dull encyclopaedic work; but if he has one, he will see the values of his subject according to it : the Marxist and the Catholic will agree on dates and facts but not on selection of material or its interpretation. The student will have to apply to either a sort of correction-factor, and discount views that bear closely on the subjects of their enthusiasm.

Even the author's psychological make-up has its influence on the history written. Most are prone to Bacon's "idols of the theatre" and produce an account much clearer and simpler than the reality : only a few are impressed by that complication and uncertainty of things which makes the man that is aware of it unwilling to assert anything positively. The "idols of the theatre " are very hard to avoid. The author finds himself with a mass of facts: he thinks "what is the theme that can form a string on which to thread these beads to make a necklace?" But in fact there are always many trends that contribute to form the actual complex of fact. To adopt but one is to falsify, to show up all is to complicate-but it is also the way to write good history.

There is your man : he does not exist, and who have we got? We have men with a deep love and enthusiasm for the subject, but with rare exceptions, who have had to give their working life to something else. We should not expect very much chemical discovery from a historian who did chemical research in his odd moments ; why should we hope for much from the converse? The progress of the subject is in the hands of the universities. If they decide that it is an important subject of study and believe this with a degree of conviction which will lead them to divert to the history of science funds badly needed elsewhere, we shall in time produce great historians of science : until then we may, I think, admire what has been done with so little aid.

I turn now to the books that should be written, and ask what a history of science should try to do. The least it can do is plainly and simply set down facts and names and dates and references and get them right. This is the foundation of history and it has not been completed. I know some histories of chemistry in which I am pretty sure that all the dates are right, but there 
is nothing like an exhaustive history of chemistry extant. If a text-book of the history of science of perhaps a couple of thousand pages, devoted wholly to facts, could be written, what an invaluable aid to research that would be! Unfortunately it is not a very interesting way to spend one's life, and in fact people much prefer to draw conclusions than to record facts, and histories of science generally have a theme. The usual one is the elucidation of the discoveries and ideas that led up to modern science. The writer is a scientist : he sees modern science as the crown of human progress and he shows how it came to be. This is interesting, but it presents a very incomplete picture. Whatever was not on the way to modern science is ignored or dismissed, too often with a sneer. Nevertheless, it is a kind of history that many people wish to read and can easily understand.

Another type of writer may seek to elucidate the history of science, taking that word to mean the discipline and its organisation. He would not be interested so much in the question of who first discovered the hygroscope or the law of expansion of gases, as to record how scientists went to work in each successive age, how their aspirations changed and how they learned to fulfil those aspirations. Such a history might include the organisation of science, its teaching and its place in the body politic.

Some writers are less interested in modern science than in the way men think and have thought about their work. The type of writer I first mentioned is quite uninterested in what, let us say, Albertus Magnus, thought about his world. He was a believer in a central earth, the four elements, the virtues of bodies and so forth: to the enthusiast for modern science this is rubbish, interesting only so far as it shows how wrong-headed an intelligent man can be. But the writer who is interested in man finds Albertus just as interesting as Newton or Darwin : to understand and enter into his point of view is a moving and instructive exercise. That Albertus was wrong-well, what does it matter: doubtless we are all wrong sub specie aeternitatis. In the shadow of God's knowledge of His universe, to distinguish between the ignorance of Albertus and that of Einstein, is to dispute the precedence of the flea and the louse-which are both equally interesting to the entomologist. That is the sort of history I would wish to be able to write - the fruit of a life of learning to see the world as the men of each former age saw it, and to gain from that seeing the satisfaction that they gained.

Lastly, sad to relate, the history of science can be written to support a thesis. Perhaps it cannot be written without being conditioned to some extent by the writer's views, but the man who adopts some principle of life and invents or selects facts to support it is committing an intellectual fraud.

The character of the histories of science that will be written is bound up with the use to which they will be put. We find, today, the study of the history of science being commended for other reasons than its place as a part of the total human knowledge, and if it is to be used for a purpose, that purpose will have to be taken into account.

Some would have the history of science to be a discipline important to older pupils of schools and to university students studying other subjects. It is felt by some to be a subject which could be presented to arts students in order to give them a notion of the place science takes and has taken in the world's affairs. More frequently it is commended as a means of taking off the rawness of the science student who cannot be persuaded to interest himself in the humanities but can be introduced to them through the study of the history of his subject. Again, it is commended as a way of introducing the 
science student to scientific methods. Books can be written for all these purposes, but not very satisfying ones. They have to be short and unduly simplified : commonly they are distorted by the emphasis that has to be laid on the analogy of the science of the past to that of the present. At a different level we find today the historian and philosopher asking for books which will help them to include the history of science in their own studies : too often these scholars have been taught no natural science and have never acquired any, and it is again impossible to write a true book to serve them. To my mind the study of the history of science for a pedagogic or ancillary purpose is secondary, while its study in and for itself is the primary need. It is, I am sure, a duty of this Society to endea vour to promote the preparation of first-class scholarly works in the history of science, written with no intention save that the truth should be told.

A book requires not only an author but a publisher and readers. Indeed it may be said that the readers determine whether a book can be published or not. It is true that a university press may sometimes publish a work which is likely to have a negligible sale, but in general a book has to pay its way. For most learned works there is a population of serious students who will buy them as apparatus of research and as a means of passing examinations. This body, for the History of Science, is a very small one, in this country at least, so that the publisher of a large dry work on the history of science can expect but a slow return of his capital. On the other hand there are, I estimate, ten or fifteen thousand interested amateurs who will buy a readable and informative popular book on the subject. Consequently the publisher wants books addressed to these amateurs and will publish other types with reluctance if at all. Thus there hare been many easy little books on the subject, but few solid works. Once more the provision of accessible means of study waits upon the universities to make the history of science a recognised department of studies. It is true that great industrial organisations may finance such works : I would instance Messrs. Peter Spence's aid to the publication of Dr. Singer's sumptuous work on Alum and I.C.I.'s sponsoring of the new History of Technology now in progress. But such help as this is more likely. to be available for the history of industries than that of pure science, though none can predict how far the generosity of these great firms may go. I hare spoken here of difficulties, but I believe that if a first-class major history of science were to be written it would not lack a publisher.

Reflections are not of much value unless they lead at least to suggestions for action. If I have persuaded you of my thesis, you will agree that the apparatus of study of the History of Science requires improvement. I would distinguish a short-term plan which could be carried out now and a long-term plan to which it might lead. For the short-term I would urge the need for a single work covering the whole field of the history of science, as distinguished from technology. This should be of such a magnitude as to be able to answer the queries of anyone but a specialist on his own subject : it should be copiously documented so as to afford references to all important primary sources. It is quite obvious that nobody in the world is capable of writing such a book : it is therefore necessary to contemplate either an encyclopaedia or a book of which chapters are contributed by different authors, as for example in the Cambridge Histories. Even on this basis it would be difficult to cover the whole of the scientific subjects that have a history, but it would be possible in subsequent editions to rewrite individual contributions and steadily increase the value of the work. I would hope that the Society may give serious thought to such a plan and explore the possibility of bringing it into effect. 
The ultimate need for the elucidation of the history of seience is that there should be more students of the subject having scholarly standards. The universities have unquestionably moved in this direction, but except for University College, London, they are not perhaps fully aware of the problem. The history of science is not a subject whose facts have been ascertained, reduced to order and generalised, and are waiting only to be taught. It is, on the other hand, a subject very imperfectly known and by no means freed from long-standing fallacies. It still awaits co-ordination within itself and with other disciplines: above all it needs the great men to write the great books. Great men arise rarely and irregularly out of a large population of good mediocrities. We, in the History of Science, need far more good mediocrities in order to increase the probability of the great man. We can in fact provide the men who will master our subject, only by teaching it to the many among whom may prove to be a gifted few, and that is the chief end that this Society, through the years, must try to promote. If, while I have served you as President, I have in any measure contributed thereto, I shall be satisfied with my work. 